Article

\title{
Can Hawaii Meet Its Renewable Fuel Target? Case Study of Banagrass-Based Cellulosic Ethanol
}

\author{
Chinh Tran* and John Yanagida \\ Department of Natural Resources and Environmental Management, University of Hawaii at Manoa, \\ 1910 East-West Road, Honolulu, HI 96822, USA; jyanagid@hawaii.edu \\ * Correspondence: chinh.tran@hawaii.edu; Tel.: +1-808-956-4065 \\ Academic Editors: Shih-Lung Shaw, Qingquan Li, Yang Yue and Wolfgang Kainz \\ Received: 9 March 2016; Accepted: 8 August 2016; Published: 16 August 2016
}

\begin{abstract}
Banagrass is a biomass crop candidate for ethanol production in the State of Hawaii. This study examines: (i) whether enough banagrass can be produced to meet Hawaii's renewable fuel target of 20\% highway fuel demand produced with renewable sources by 2020 and (ii) at what cost. This study proposes to locate suitable land areas for banagrass production and ethanol processing, focusing on the two largest islands in the state of Hawaii-Hawaii and Maui. The results suggest that the $20 \%$ target is not achievable by using all suitable land resources for banagrass production on both Hawaii and Maui. A total of about 74,224,160 gallons, accounting for $16.04 \%$ of the state's highway fuel demand, can be potentially produced at a cost of $\$ 6.28 /$ gallon. Lower ethanol cost is found when using a smaller production scale. The lowest cost of $\$ 3.31 /$ gallon is found at a production processing capacity of about 9 million gallons per year (MGY), which meets about $2 \%$ of state demand. This cost is still higher than the average imported ethanol price of $\$ 3 /$ gallon. Sensitivity analysis finds that it is possible to produce banagrass-based ethanol on Hawaii Island at a cost below the average imported ethanol price if banagrass yield increases of at least $35.56 \%$.
\end{abstract}

Keywords: banagrass; ethanol; Hawaii Island; Maui Island; land suitability model; linear programming model

\section{Introduction}

Energy use in the state of Hawaii has been heavily dependent on fossil fuels [1]. In 2011, energy consumption from petroleum and coal were $86.1 \%$ and $5.6 \%$, respectively [2]. Expenditures for petroleum products accounted for $97.4 \%$ of Hawaii's energy expenditure [2]. All motor gasoline in the state of Hawaii has been produced from imported crude oil by Hawaii Independent Energy (formerly Tesoro) and Chevron refineries [3]. Having no natural fossil fuel resources, Hawaii must rely entirely on imported fuels from abroad, which places the state in a vulnerable energy security situation [4-7]. In a step aimed at reducing the dependence on fossil fuel and protecting the environment, the state has required the use of renewable energy resources [4-6]. For the transportation sector, the state mandates a statewide alternate fuels standard (AFS) of $10 \%$ of highway fuel demand by $2010,15 \%$ by $2015,20 \%$ by 2020 , and $30 \%$ by 2030 [8].

Gasoline in Hawaii is now known as E10, which is composed of at least $90 \%$ petroleum and up to $10 \%$ ethanol produced from cellulosic materials [3]. However, there has been no ethanol production for its own consumption in Hawaii. Ethanol is essentially imported from other sources [3,9]. The average imported ethanol price in 2014 was calculated at about $\$ 3.00$ /gallon based on [2] and from discussions with the Department of Business, Economic Development \& Tourism, State of Hawaii.

To promote ethanol production, the state provides investment tax credit incentives equal to $30 \%$ of the ethanol nameplate capacity of 40 million gallons per year (MGY) [10,11]. Several studies have shown that ethanol production from lignocellulosic biomass feedstock is feasible in Hawaii $[1,4,6,12,13]$. 
A number of lignocellulosic biomass feedstock such as banagrass, sugarcane, Eucalyptus, and Leucaena were selected as potential energy feedstock candidates for ethanol production in Hawaii [4,12-15].

Previous studies generally analyzed potential ethanol production in the state of Hawaii by comparing different biomass energy crops in specific locations and by estimating possible ethanol nameplate capacity $[1,12-15]$. Banagrass showed strong potential to produce high biomass yields based on several field trials performed in Hawaii [14] and high net returns as compared to other energy crops. Cost analysis of banagrass-based ethanol production on the island of Hawaii was done earlier by [16]. Mochizuki (2013)'s research objective was to optimally select banagrass production sites and ethanol processing plant locations on Hawaii Island to minimize the cost of ethanol production in meeting the $20 \%$ of highway fuel demand by 2020 . Spatial analysis was used to locate potential areas for banagrass feedstock production. A land suitability model was employed. The study used a secondary map layer detailing Agricultural Lands of Importance to the State of Hawaii, which were compiled and drafted in 1977 by the State Department of Agriculture [17]. Possible discrepancies with the selected land areas were due to the expansion of residential areas and other development projects over time. Also, the estimation of potential biomass yield was calculated solely on soil temperature and moisture regimes under annual rain-fed conditions. This study extends/modifies work done earlier [16] by examining other factors that affect crop yield, including precipitation, air temperature, and solar radiation. This study also seeks to further develop and improve suitability analysis and crop yield estimates in order to improve estimation of ethanol production potential and possibly lower banagrass production costs in the state of Hawaii. The analytical process includes using various data sources, following strict criteria, and high spatial resolution satellite imagery from Google Earth and Microsoft Aerial Bing Maps.

This study focuses on Hawaii and Maui Islands, in the state of Hawaii. The overall study objective is to determine how much ethanol can be produced from the banagrass feedstock if production and processing locations are optimally located on these two islands. Specifically, this study seeks to answer the following research questions: (i) Can the legislatively mandated 20\% of the state's highway fuel demand by 2020 be met by using banagrass as the primary feedstock for ethanol production in the state of Hawaii? (ii) Is the cost of locally produced ethanol less expensive than the cost of imported ethanol?

\section{Materials and Methods}

\subsection{Study Areas and Data}

The administrative boundary for Hawaii and Maui Islands in the state of Hawaii is shown in Figure 1. Hawaii and Maui are the two largest islands in the state with total land areas of $10,458.85 \mathrm{~km}^{2}$ $\left(2,584,440\right.$ acres) and $1888.63 \mathrm{~km}^{2}$ (466,690 acres), respectively. Land for agriculture and conservation uses constitute large portions of land use for these islands. Agriculture and conservation account for $45.8 \%$ and $52.0 \%$ of the total land area on Hawaii Island and $50.4 \%$ and $43.7 \%$ on Maui Island, respectively [18].

The land resource plays an important role for biomass feedstock production. The State Department of Agriculture established Agricultural Lands of Importance to the State of Hawaii (ALISH) and Agricultural Land Use Map (ALUM), which were digitized in ArcGIS layers and provided by the Office of State Planning (OSP) [19]. ALISH characterized three classes of agriculturally important lands, including (i) prime agricultural lands that have the soil quality and moisture supply best suited for the production of food, feed, forage, and fiber crops; (ii) unique agricultural lands that are used for the production of specific high-value food crops such as coffee, taro, rice, and non-irrigated pineapple; (iii) and other important agricultural lands that are statewide or locally important for the production of food, feed, fiber, and forage crops excluded from the prime or unique agricultural land classifications [17]. ALUM provides information about the type of agricultural land use in terms of the specific crops grown. The map layers were downloaded from the Office of State Planning, State of Hawaii website [19]. 


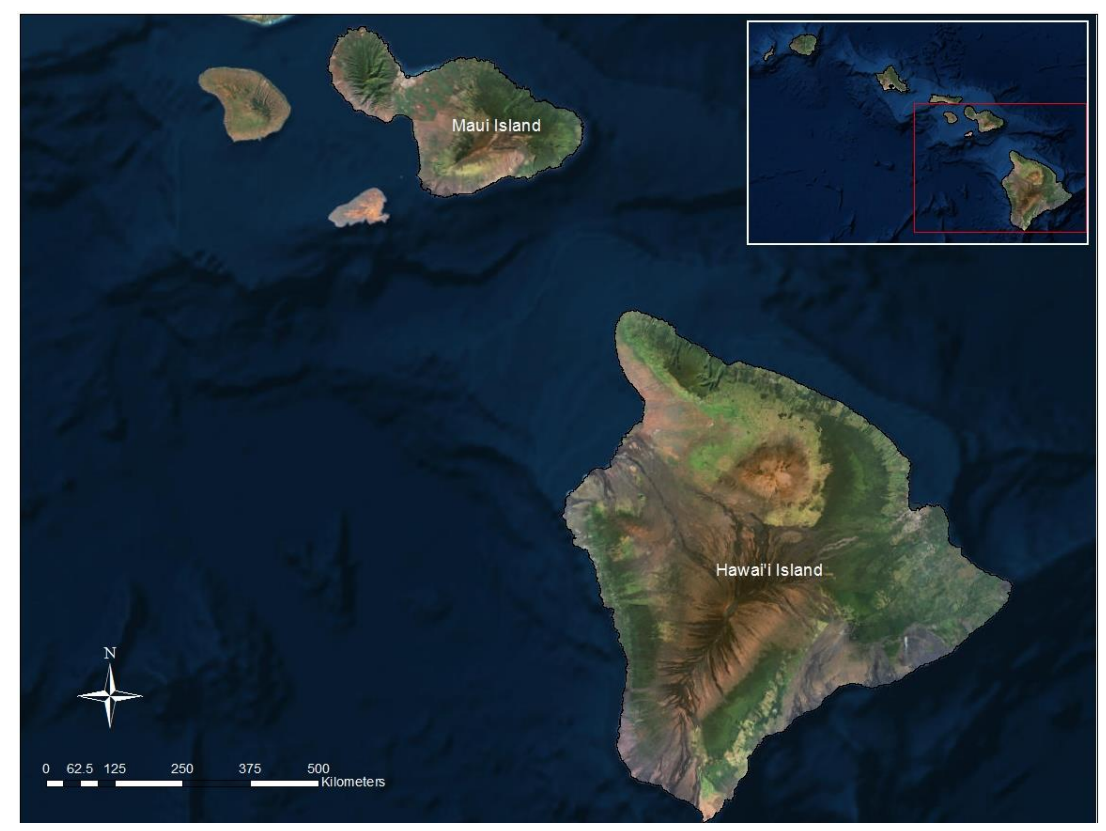

Figure 1. Administrative boundary of Hawaii and Maui Islands.

Detailed soil maps that characterize the soil temperature and soil moisture regimes of Hawaii and Maui Islands were obtained from the Web Soil Survey (WSS), which provides soil data produced by the National Cooperative Soil Survey, USDA Natural Resources Conservation Service (NRCS) [20]. Soil temperature regimes are characterized by isohyperthermic (hot), isothermic (cool), and isomesic (cold) conditions. Soil moisture regimes include aridic (dry), ustic (moist), udic (wet), and aquic (saturated) conditions [1]. The terms hot, cool, and cold for soil temperature and dry, moist, wet, and saturated for soil moisture are used from this point forward. Banagrass yields on a dry matter basis associated with each soil condition were estimated based on several field trials performed in Hawaii $[1,14]$.

Detailed street maps for Hawaii and Maui Islands were extracted from the U.S. and Canada detailed street data downloaded from ESRI's website [21]. Multilane divided expressways or principal highways by the State of Hawaii were selected [19]. The street map represents detailed streets, interstate highways, and major roads for each island. Rainfall and other climate data were obtained from the online Rainfall Atlas of Hawaii and Climate of Hawaii, Department of Geography, University of Hawaii at Manoa [22,23]. Statistics on gasoline demand and the price of ethanol imported by the state of Hawaii were retrieved and calculated from the historical monthly energy data for Hawaii [24] and the U.S. Energy Information Administration [25]. Other data include 90-m resolution Digital Elevation Model (DEM) downloaded from [26], spatial distribution of volcanos obtained from [27], and inland water resources, Tax Map Key (TMK) parcels for counties of Hawaii and Maui, and reserved land map layers retrieved from the Office of State Planning website [19].

\subsection{Methods}

The Methodological Flowchart used for this study is illustrated in Figure 2. The land suitability model uses Analytic Hierarchy Process (AHP) combined with Geographic Information System (GIS) to determine suitable banagrass production areas and ethanol processing sites. A linear programming (LP) model minimizes ethanol production costs by optimally selecting land locations for banagrass production and ethanol processing. The GIS-based approach using ArcGIS version 10.1 (ESRI, Redlands, CA, USA) and mathematical methods using MATLAB R2013a (MathWorks, Natick, Massachusetts, USA) are applied in this study. 


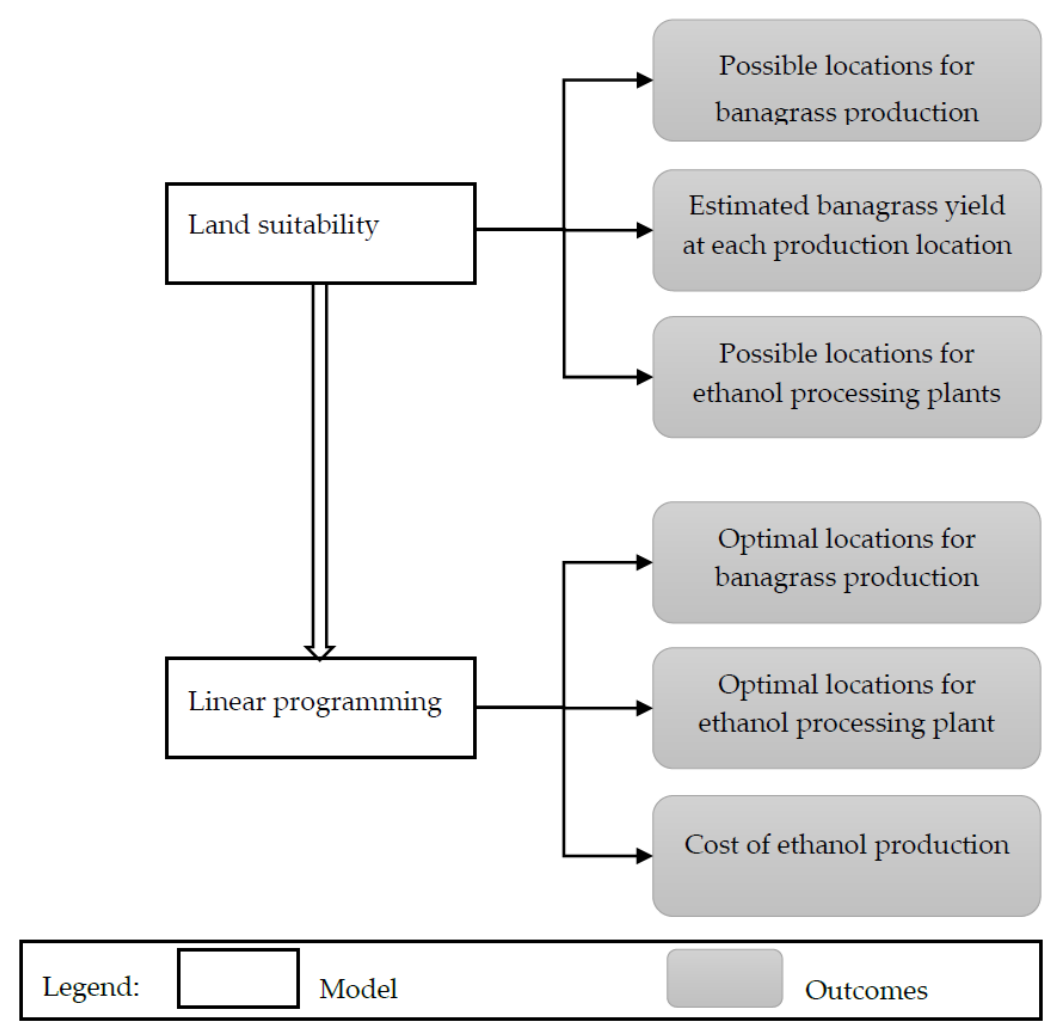

Figure 2. Methodological flowchart.

\subsubsection{Land Suitability Model}

In the land suitability model, lands dedicated to the energy crop and ethanol processing were identified by considering land topography, current land use, soil temperature and moisture regimes, rainfall characteristics and other climate factors, etc. The model was built on several important factors and criteria identified by the Clean Fuels Development Coalition $[4,13,14,16,28-30]$. The model addresses two objectives: (i) identify possible land locations for banagrass production and estimating corresponding banagrass yield at each location; and (ii) determine possible locations for ethanol processing plants.

\section{- Data preparation}

Data preparation is critical in order to exclude areas that are not feasible for banagrass production by employing a series of overlay operations. Banagrass is known as a tropical grass found in most tropical or subtropical countries [31]. High-altitude areas with elevation above $2000 \mathrm{~m}$ were found to be unsuitable for banagrass production and were not considered as land candidates. Areas affected by natural hazards such as volcanoes or reserved for different purposes such as forest reserves, sanctuaries, parks, historic sites, military installations, and others were also excluded. To avoid competing with lands currently growing agricultural crops and engaged in related activities, these were excluded. Land areas classified as pasture land and non-prime, non-unique agricultural lands, as categorized in ALUM and ALISH map layers, were selected as potential land candidate for banagrass production.

This study assumed mechanized banagrass production management and harvesting. Therefore, land types, slope gradient, and road conditions play important roles and were taken into consideration. All land areas categorized as sandy, very rocky or stony, extremely stony, and rough broken land in the soil survey [20] were excluded from possible production areas. Slope gradient measured as percentage rise was calculated from the Shuttle Radar Topography Mission (SRTM) 90-m resolution Digital Elevation Model (DEM). Different harvesting techniques require different slope limits in 
order to operate machines [32]. A slope gradient less than $20 \%$ was found to be suitable for grass crops [13]. As a result, lands located in areas with slope gradient exceeding $20 \%$ were not considered. Biomass feedstock transportation requires frequent and heavy truck hauling operations. Therefore, road conditions play a critical role. Land areas adjacent to existing major highways classified as multiplane divided expressways or principal highways on Hawaii and Maui Islands were selected [19].

The next important step in the land suitability model is the ground-truthing process to validate the potential production land areas resulting from the operations. Since the map layer data of ALUM and ALISH were produced in the 1970s, it is possible there could be more recent residential development areas mixed with other land projects. The resulting land areas were then cross-checked with TMK parcel maps (most recently updated in 2013) by the State Office of Planning to define specific land owners and land use purposes [19]. The areas characterized as agricultural and rural lands by attribute were selected for further consideration. The final land selection was based on the process of ground-truthing to help improve the quality of the analysis by using high spatial resolution satellite imagery from Google Earth and Microsoft Aerial Bing Maps. All the shapefile layers were projected to the coordinate system NAD 1983 UTM Zone 4N and processed for Hawaii and Maui Islands. The result was the shapefile layer presenting possible land areas for growing banagrass feedstock. Data for these areas were retrieved for land suitability analysis and LP model.

- $\quad$ AHP and GIS for banagrass yield assessment

The integration of AHP and GIS for the land suitability model has been widely used in various studies, such as landfill selection in Konya's Lake Beyşehir catchment area, Turkey [33], urban development in a secondary city of Bangladesh [34], and site evaluation for ecotourism [35]. AHP is a multi-criteria decision-making technique based on decision theory to determine which criteria are the most important. This paper uses a technique to evaluate land suitability levels for banagrass production. The AHP model reports the weight of each factor and the consistency of the results is validated by calculating a consistency ratio (CR). The threshold $C R$ value is 0.1 . A CR value less than 0.1 indicates an acceptable level of consistency in pairwise comparisons. A CR value greater than or equal to 0.1 indicates that the criteria should be reexamined until $C R$ reaches the consistency level less than 0.1. The use of other studies, expert judgments, and experimental data are important to determine the ranking system for the pairwise comparison matrix in AHP.

The first step is to identify the critical factors affecting banagrass growth. Four critical factors were considered in this study, including soil temperature and moisture regimes, precipitation, minimum temperature, and solar radiation. These critical factors were selected based on a series of studies by Black and Veatch (2010), Ferraris (1978); Ferraris and Sinclair (1980); and Ferraris, Mahony and Wood (1986) [1,36-38]. Each critical factor has its own set of attributes that also has effects on banagrass growth. These attributes were retrieved according to the conditions on Hawaii and Maui Islands and categorized into different groups (Table 1). Soil temperature and moisture regimes were divided into different groups by combining temperature conditions and moisture regimes such as hot and wet; hot and moist; hot and saturated; etc. Other factors-precipitation, minimum temperature, and solar radiation-were categorized into five groups by applying the commonly used Jenks natural breaks classification method [39] in ArcGIS, which is a data clustering method designed to determine the best arrangement of values for different classes. This was done by minimizing each class's average deviation from the class mean, while maximizing each class's deviation from the means of the other groups. In other words, this method reduces the variance within classes and maximizes the variance between classes. 
Table 1. Critical factors affecting banagrass yield.

\begin{tabular}{|c|c|c|}
\hline Criteria & Data Sources & Attributes \\
\hline Soil temperature and moisture regimes & [20] & $\begin{array}{c}\text { Hot, wet } \\
\text { Hot, moist } \\
\text { Hot, saturated } \\
\text { Cool, moist } \\
\text { Cool, wet } \\
\text { Cold, wet } \\
\text { Cold, moist } \\
\text { Cool, saturated }\end{array}$ \\
\hline Precipitation (mm) & [22] & $\begin{array}{c}385-1044 \\
1044-1881 \\
1881-3732 \\
3732-5456 \\
5456-6851\end{array}$ \\
\hline Minimum temperature (Celsius) & [23] & $\begin{array}{c}4.12-7.79 \\
7.79-10.59 \\
10.59-13.08 \\
13.08-16.13 \\
16.13-20.00\end{array}$ \\
\hline Solar radiation $\left(\mathrm{W} / \mathrm{m}^{2}\right)$ & [23] & $\begin{array}{l}163.78-188.74 \\
188.74-205.95 \\
205.95-221.44 \\
221.44-238.22 \\
238.22-273.52\end{array}$ \\
\hline
\end{tabular}

The next step was to determine the weights of the four critical factors and the weights of attributes within each critical factor. The primary objective for this step in AHP analysis is to determine the ranking of criteria and to compare their rankings by constructing a pairwise comparison matrix. The numerical values $1,3,5,7$, and 9 were assigned to indicate if one factor is thought to be equally important, moderately more important, strongly more important, very strongly more important, and strictly superior in comparison with the other criteria in a pairwise comparison, respectively. Given the four critical factors and attributes, there were five sets of AHP results to estimate the weight of each factor and the weight of each attribute within each factor. This study used both (i) experimental data and (ii) expert's judgments for this step.

(i) The experimental data were collected from several banagrass field trials located on the Hawaiian Commercial \& Sugar Company (HC\&S) land on Maui Island. Monitoring of banagrass yields, soil characteristics, and daily weather conditions on the field trials was done from 2012 to 2015 as a part of the USDA/NIFA Biomass Research and Development Initiative (BRDI) project at the University of Hawaii at Manoa. These study results are also a part of the BRDI project.

(ii) Dr. Richard Ogoshi, Department of Tropical Plant \& Soil Sciences, University of Hawaii at Manoa, is the task leader in charge of working on banagrass field trials. He is an agronomist/soil scientist who works with researchers from HC\&S to monitor, collect, and analyze the effects of weather conditions and soil characteristics, etc. on banagrass yields over the years. For Hawaii, he is the lead expert in this field. We consulted with him regarding determination of the ranking system for the pairwise comparison matrix that is used in conducting AHP analysis for the four critical factors and their attributes.

Dr. Ogoshi is the leading expert who works with researchers (other experts) from a different organization (HC\&S) on the same research project (BRDI). A recent AHP study by de FSM Russo and Camanho (2015) reviewed the literature (33 other AHP studies) thoroughly but used only one expert in their AHP analysis [40]. Another study, Tsyganok et al. (2012), suggests that " ... if the 
number of experts in a group is relatively small, expert competence should always be taken into consideration" [41].

Of the four critical factors, soil temperature and moisture regimes appear to be the most important factors, followed by precipitation. Minimum temperature and solar radiation are less important as compared to other factors. Therefore, a value of 5 is assigned to indicate that soil temperature and moisture regimes are thought to be strongly more important than precipitation. A value of 3 meant that precipitation is moderately more important than minimum temperature or solar radiation. The same procedure was done to create the full pairwise comparison matrix for AHP analysis for the critical factors.

This procedure was also applied for AHP analyses to determine the weights of attributes for each critical factor. For example, higher banagrass yield likely occurred in the locations with higher soil temperature and moisture conditions. Hot and wet soil is thought to have a higher yield as compared to other attributes of soil temperature and moisture regimes. A value of 3 indicated that hot and wet soil is thought to be moderately more important than hot and moist soil; a value of 5 meant hot and wet soil is thought to be strongly more important hot and saturated soil; or a value of 9 showed that hot and wet soil is strictly superior to cold and moist soil, etc. For other critical factors, higher banagrass yield is thought to be associated with higher solar radiation, higher minimum temperature and precipitation ranging from $1000 \mathrm{~mm}$ to $5000 \mathrm{~mm}$ as compared to other attributes within the solar radiation, minimum temperature, and precipitation factors. All these conditions were used in building pairwise comparison matrices to estimate the weights of factors and their attributes that determine suitable areas for banagrass production.

The AHP results were then inputted to the related layers for weighted overlay operations processed in ArcGIS version 10.1. These overlay operations were used to locate suitable banagrass production areas for Hawaii and Maui Islands.

The estimation of banagrass yield in natural conditions was based on the study by [1] and validated by data collected from several field trials on Maui during the period from 2012 to 2015 [42]. The estimated yield data were then compiled to estimate potential biomass production on Hawaii and Maui Islands and the potential ethanol production for the state of Hawaii based on the banagrass biomass feedstock.

- Land selection for ethanol processing plants

Proper siting of an ethanol plant is critical to economically develop renewable energy alternatives. To account for logistical, social, and environmental concerns, a guide was developed by the Clean Fuels Development Coalition (CFDC) and the Nebraska Ethanol Board in 2006. This guide [28] suggests that the land area for an ethanol processing plant should be at least 40 acres. This land area should provide enough space for on-site transportation and future development of the ethanol plant. Properly located, this plant should not impose potential problems with neighboring community and residential areas. Following this requirement, the ethanol plant location should also be within the biomass feedstock production areas prescribed by the land suitability model. Land areas less than 40 acres and/or near to community and residential locations were excluded from further plant location consideration. Other criteria used in the plant location process include transportation and water requirements [28]. Possible processing sites should include a 3200-m buffer zone around major highways [16,30] and availability of aquifer systems to meet sustainable yields for water demands in 2025 [16]. The presence of sustainable water aquifers was stated in the Hawaii and Maui counties' water use and development plans $[43,44]$. These data were processed and resulted in land locations that meet all requirements for the ethanol processing plant site selection. These processing ethanol plants were located at the center of each island's banagrass production sites. 


\subsubsection{LP Model}

The overall objective of the LP model is to minimize the cost of ethanol production in order to meet $20 \%$ of the state's highway fuel demand by 2020 . Results from the LP model include the lowest estimated unit cost for ethanol production, the land areas and their locations needed to produce the target amount of banagrass feedstock such that this feedstock can be processed into ethanol to meet the ethanol demand targets. The framework for the LP model is presented in Figure 3. The program involves several cost components, including the costs of banagrass feedstock production, feedstock transportation, ethanol conversion, and ethanol transportation.

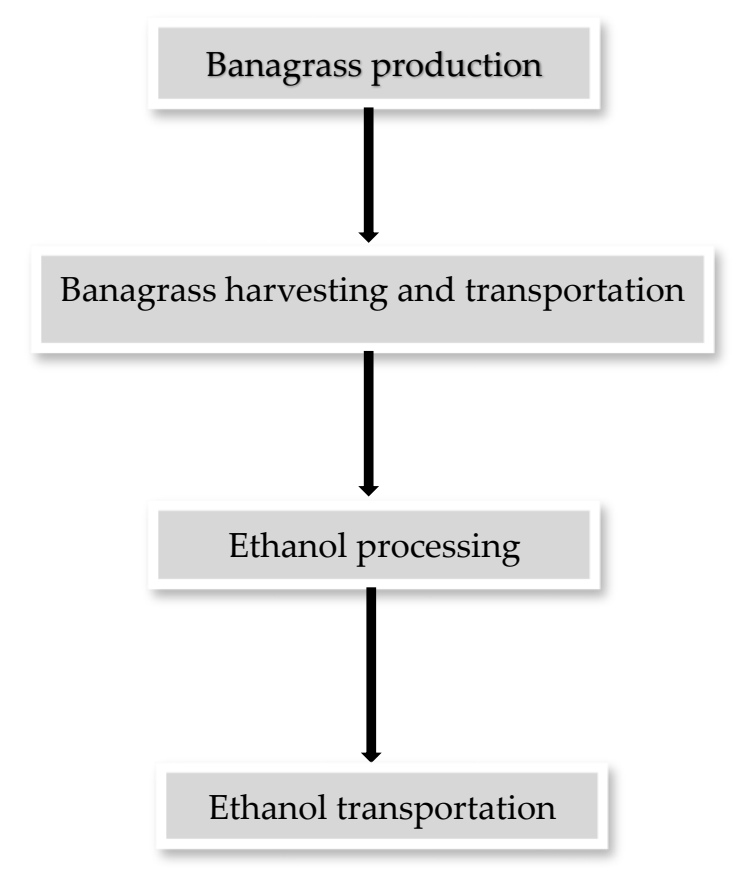

Figure 3. Framework for cost minimization analysis.

To obtain data for the LP model, $1-\mathrm{km}^{2}$ grid cells were created and used to delineate possible locations for banagrass production. The land areas and corresponding estimated banagrass yield that falls within the grid cells were retrieved as inputs for the LP model. The center point of each grid cell was generated in order to estimate distances from production areas to the ethanol processing plants and then to harbor ports on each island using network analysis. This analysis aims to minimize transportation costs by using the calculated distances from the center of each banagrass production grid cell to destination locations through the origin-destination (OD) cost matrix analysis integrated in ArcGIS version 10.1. The detailed street map for Hawaii and Maui Islands [45] were used to create this network dataset. The OD cost matrix calculates least-cost paths from production areas to the ethanol processing plants, from production areas to harbor ports and from ethanol processing plants to harbor ports for each island. These data are the inputs to the cost analyses for feedstock production and transportation, and ethanol processing and transportation.

The first component of the cost analysis is the cost of banagrass feedstock production, assuming that feedstock production occurs on both Hawaii and Maui Islands. GIS data on possible locations of land available for banagrass production and the corresponding yields associated with each location are used as inputs in the program. Let $x_{i}$ be the land area variable at each location $i$ on the island of Hawaii, $i \in\{1,2, \ldots, n\}$ and $x j$ be the land area variable at each location $j$ on the island of Maui, $\mathrm{j} \in\{1,2, \ldots, \mathrm{m}\}$. These variables represent the land areas selected for feedstock production, measured in $\mathrm{km}^{2}$. The feedstock production equation is shown as: 


$$
\left\{\begin{array}{l}
\sum_{i=1}^{n} x_{i} * y_{i}=Y_{1} \\
\sum_{j=1}^{m} x_{j} * y_{j}=Y_{2} \\
0 \leq x_{i} \leq a_{i} \\
0 \leq x_{j} \leq a_{j} \\
0 \leq y_{i}, y_{j} \\
0 \leq y_{j}
\end{array}\right.
$$

where $a_{i}$ and $y_{i}$ denote the maximum land area availability and the estimated banagrass yield at production location $i$ on Hawaii Island, respectively; $a_{j}$ and $y_{j}$ represent the maximum land area availability and estimated yield at production location $j$ on Maui Island, respectively; and $Y_{1}$ and $Y_{2}$ are the total amount of feedstock in dry tons produced on Hawaii and Maui Islands, respectively. The costs of feedstock production on Hawaii and Maui Islands are expressed as $\mathrm{C}_{\mathrm{F} 1}$ and $\mathrm{C}_{\mathrm{F} 2}$, respectively, and calculated via Equation (2):

$$
\left\{\begin{array}{l}
\mathrm{C}_{\mathrm{F} 1}=\mathrm{c} * \sum_{\mathrm{i}=1}^{\mathrm{n}} \mathrm{x}_{\mathrm{i}} \\
\mathrm{C}_{\mathrm{F} 2}=\mathrm{c} * \sum_{\mathrm{j}=1}^{\mathrm{m}} \mathrm{x}_{\mathrm{j}}
\end{array}\right.
$$

where $\mathrm{c}$ is the cost of feedstock production per hectare (ha) per year. This includes the costs of land preparation, planting, field operations such as fertilizers, herbicides for weed control and other field operations, harvesting, other operations, and operating overhead [1,14].

The second component of the cost analysis involves banagrass feedstock transportation from production areas to the ethanol processing plant. Assuming that ethanol will be processed at one processing plant on either Hawaii or Maui Islands, the transportation logistics and costs are comprised of two parts-ground transportation and interisland shipping. Distances for feedstock ground transport are measured in kilometers $(\mathrm{km})$ and are calculated based on a round-trip basis. The transportation cost calculation depends on where ethanol processing occurs. Equation (3) shows the case where ethanol is processed on Hawaii Island.

$$
\left\{\begin{array}{l}
\mathrm{C}_{\mathrm{FT} 11}=\sum_{\mathrm{i}=1}^{n} \mathrm{x}_{\mathrm{i}} * \mathrm{y}_{\mathrm{i}} * \alpha+\sum_{\mathrm{i}=1}^{\mathrm{n}} \mathrm{x}_{\mathrm{i}} * \mathrm{y}_{\mathrm{i}} * \mathrm{D}_{\mathrm{i}} * \beta \\
\mathrm{C}_{\mathrm{FT} 12}=\sum_{j=1}^{m} \mathrm{x}_{\mathrm{j}} * \mathrm{y}_{\mathrm{j}} * \alpha+\sum_{\mathrm{j}=1}^{m} \mathrm{x}_{\mathrm{j}} * \mathrm{y}_{\mathrm{j}} * \mathrm{D}_{\mathrm{jk}} * \beta \\
\mathrm{C}_{\mathrm{FT} 13}=\mathrm{W}_{11} *\left(\gamma+\mathrm{D}_{\mathrm{h}} * \beta\right)+\mathrm{W}_{12} *\left(\gamma+\mathrm{D}_{\mathrm{k}}\right) \\
\mathrm{W}_{11}+\mathrm{W}_{12}=\sum_{\mathrm{j}=1}^{\mathrm{m}} \mathrm{x}_{\mathrm{j}} * \mathrm{y}_{\mathrm{j}} * \alpha
\end{array}\right.
$$

Feedstock produced on Hawaii Island is transported directly to the ethanol processing plant. Feedstock produced on Maui Island will be hauled by heavy truck-trailers from production areas to Kahului port, then shipped to Hilo or Kawaihae or both ports on Hawaii Island before being transported to the ethanol processing plant. Variables $\mathrm{C}_{\mathrm{FT} 11}, \mathrm{C}_{\mathrm{FT} 12}$, and $\mathrm{C}_{\mathrm{FT} 13}$ are the costs of feedstock transportation from production areas on Hawaii Island to the processing plant; production areas on Maui Island to Kahului port; and inter-island shipping and ground transportation from Kahului port on Maui Island to the ethanol processing plant on Hawaii Island through Hilo or Kawaihae ports. Variables $D_{i}$ and $D_{j k}$ represent distances (measured in $\mathrm{km}$ ) from feedstock production locations $\mathrm{i}$ on Hawaii Island to the ethanol processing plant and feedstock location $\mathrm{j}$ on Maui Island to Kahului port. The terms $\alpha$ and $\beta$ are the fixed and variable ground transportation costs (measured in $\$ /$ dry ton and $\$ /$ dry ton $/ \mathrm{km}$ ); $W_{11}$ and $W_{12}$ denote the amount of feedstock shipped to Hilo and Kawaihae harbors on the island of Hawaii; $D_{h}$ and $D_{k}$ denote distances from Hilo and Kawaihae ports to the ethanol plant; and $\gamma$ is the interisland shipping cost measured in $\$ /$ dry ton. 


$$
\left\{\begin{array}{l}
C_{\mathrm{FT} 21}=\sum_{j=1}^{m} x_{j} * y_{j} * \alpha+\sum_{j=1}^{m} x_{j} * y_{j} * D_{j} * \beta \\
C_{\mathrm{FT} 22}=\sum_{i=1}^{n} x_{i} * y_{i} * \alpha+\sum_{i=1}^{n} x_{i} * y_{i} * D_{i h} * \beta \\
C_{\text {FT23 }}=\sum_{i=1}^{n} x_{i} * y_{i} * \alpha+\sum_{i=1}^{n} x_{i} * y_{i} * D_{i k} * \beta \\
C_{\text {FT24 }}=Y_{1} *\left(\gamma+\alpha+D_{k p} * \beta\right)
\end{array}\right.
$$

Equation (4) presents the case for ethanol processing on Maui Island. For this case, inter-island shipping occurs in order to transport feedstock produced on Hawaii Island to Maui Island for ethanol processing. The transportation logistics include feedstock ground transportation from production areas to either Hilo or Kawaihae ports on Hawaii Island and inter-island shipping to the Kahului port on Maui Island and ground transportation to the ethanol processing plant. The transportation costs are featured as $\mathrm{C}_{\mathrm{FT} 22}, \mathrm{C}_{\mathrm{FT} 23}$, and $\mathrm{C}_{\mathrm{FT} 24}$. Feedstock produced on Maui Island is transported directly to the ethanol processing plant and the transportation cost is $C_{F T 21}$. $D_{j}$ denote distances from feedstock production sites on Maui to the ethanol processing plant; $D_{i h}$ and $D_{i k}$ represent distances from feedstock production sites on Hawaii Island to Hilo and Kawaihae ports; and $D_{k p}$ indicates distance from Kahului port to the ethanol processing plant on Maui Island.

The total feedstock transportation cost is given in Equation (5):

$$
\begin{cases}\mathrm{C}_{\mathrm{FT}}=\mathrm{C}_{\mathrm{FT} 11}+\mathrm{C}_{\mathrm{FT} 12}+\mathrm{C}_{\mathrm{FT} 13} & \text { if ethanol processing is on Hawaii island } \\ \mathrm{C}_{\mathrm{FT}}=\mathrm{C}_{\mathrm{FT} 21}+\mathrm{C}_{\mathrm{FT} 22}+\mathrm{C}_{\mathrm{FT} 23}+\mathrm{C}_{\mathrm{FT} 24} & \text { if ethanol processing is on Maui island }\end{cases}
$$

The third component is ethanol conversion costs. Since feedstock is transported to the ethanol plant immediately after harvesting, it is assumed that the moisture content remains the same as it was at the time of harvesting $[14,46]$. Cleaning and size reduction processes are accomplished at the ethanol plant. Ethanol production cost is calculated on a dry basis and given as:

$$
\mathrm{C}_{\mathrm{E}}=\mathrm{c}_{\mathrm{ef}}+\mathrm{c}_{\mathrm{vf}} * \delta * \mathrm{Y}
$$

where $C_{E}$ is the ethanol processing cost (in $\$$ ); $\delta$ is the rate of banagrass size reduction at the plant (in $\%)$; and $\mathrm{c}_{\mathrm{ef}}$ and $\mathrm{c}_{\mathrm{vf}}$ represent the fixed cost and variable cost of production per dry ton of feedstock (\$/dry ton), Respectively.

The last component is the cost of ethanol transportation to Oahu for blending. Let $\psi$ denote the ethanol conversion rate. Ethanol will be transported to either Hilo or Kawaihae ports if ethanol processing occurs on Hawaii Island or to Kahului if ethanol processing is on Maui Island. The produced ethanol will then be shipped to Oahu for blending with gasoline to produce E10 automobile fuel. Total ethanol produced and the transportation costs to the blending sites are calculated as:

$$
\begin{cases}\mathrm{C}_{\mathrm{ET} 1}=\delta * \mathrm{Y} * \varphi * \mathrm{c}_{\mathrm{e} 1} * \mathrm{c}_{\mathrm{et}}\left(\mathrm{D}_{\mathrm{h}}+\mathrm{D}_{\mathrm{k}}\right) & \text { if ethanol processing is on Hawaii Island } \\ \mathrm{C}_{\mathrm{ET} 2}=\delta * \mathrm{Y} * \varphi * \mathrm{c}_{\mathrm{e} 2} * \mathrm{c}_{\mathrm{et}} \mathrm{D}_{\mathrm{kp}} & \text { if ethanol processing is on Maui Island }\end{cases}
$$

where $\mathrm{C}_{\mathrm{ET} 1}$ and $\mathrm{C}_{\mathrm{ET} 2}$ denote the ethanol transportation cost on Hawaii and Maui Islands, respectively; $c_{\mathrm{et}}$ is the ethanol transportation cost per $\mathrm{km}$; and $\mathrm{c}_{\mathrm{e} 1}$ and $\mathrm{c}_{\mathrm{e} 2}$ are the inter-island shipping cost per gallon $(\$ /$ gallon $/ \mathrm{km}$ ) from Hawaii Island to Oahu and from Maui Island to Oahu.

From Equations (1)-(7), the cost optimization objective function is:

$$
\text { Min } \operatorname{cost} C=\mathrm{C}_{\mathrm{F}}+\mathrm{C}_{\mathrm{FT}}+\mathrm{C}_{\mathrm{E}}+\mathrm{C}_{\mathrm{ET}}
$$

All variables are positive. Parameters for the analysis were proxied by using estimates from related and relevant studies. All monetary values are inflated to their 2014 value by using CPI indexes. 
These monetary variables include the estimated banagrass production cost of $\$ 1386.27 /$ acre [14], ethanol processing variable and fixed annual costs for a 1MGY facility with corresponding costs of $\$ 1.19$ /gallon and $\$ 600,700$, respectively [46], feedstock transportation variable and fixed costs of $\$ 0.18 /$ dry ton $/ \mathrm{km}$ and $\$ 6.79 /$ dry ton, respectively [47], ethanol distribution cost of $\$ 0.18 / \mathrm{ton} / \mathrm{km}$ [48], feedstock inter-island shipping cost of $\$ 136.67 /$ wet ton [49] and ethanol inter-island shipping costs of $\$ 0.15 /$ gallon and $\$ 0.11 /$ gallon from Hawaii and Maui Islands to Oahu Island, respectively [50].

\section{Results and Discussions}

\subsection{Land Suitability Model}

The land suitability model identifies the possible land locations for banagrass production and location candidates for an ethanol processing plant on Hawaii and Maui Islands. The data preparation process examines the land areas that meet all the requirements for banagrass production. A total of 70,373 ha of land located on both islands-59,500 ha on Hawaii Island and 10,873 ha on Maui Island-is determined as potential area for production. The analytical hierarchy process (AHP) and geographic information system (GIS) methods were used to evaluate land suitability and corresponding banagrass yields for the selected areas.

AHP analysis determined that of the four criteria factors used (soil temperature and moisture regimes, precipitation, minimum temperature, and solar radiation), soil temperature and moisture regimes and precipitation are the most important factors with weights measured at $64 \%$ and $22 \%$, respectively. Minimum temperature and solar radiation have lower and equal weights of $7 \%$ (Table 2). When examining the attributes of each criteria factor, hot and wet soil is the most important attribute for the soil temperature and moisture regimes criteria with a weight of $40 \%$. This was followed by the hot and moist soil regimes factor with a weight of $23 \%$. For the annual precipitation criteria, the leading attributes had annual precipitation ranges of 1881-3732 and 3732-5456 millimeters with weights of $52 \%$ and $25 \%$, respectively. The overall weight for each criterion is calculated by multiplying the criteria weight by the corresponding attribute weight. The results suggest that areas characterized by hot and wet soil regime, annual precipitation ranging from 1881 to $3732 \mathrm{~mm}$, minimum temperature ranging from $13.08-20^{\circ} \mathrm{C}$ and solar radiation in the 238.22 to $273.52 \mathrm{w} / \mathrm{m}^{2}$ range are the most suitable for banagrass production.

Table 2. AHP results for land suitability for banagrass production.

\begin{tabular}{ccccc}
\hline Criteria & Criteria Weight & Attribute Values of Criteria & Attribute Weight & Overall Weight \\
\hline & & Hot, wet & 0.40 & 0.26 \\
& Hot, moist & 0.23 & 0.15 \\
Soil temperature & & Hot, saturated & 0.13 & 0.08 \\
and moisture & 0.64 & Cool, moist & 0.06 & 0.04 \\
regimes & & Cool, wet & 0.06 & 0.04 \\
& & Cold, wet & 0.06 & 0.04 \\
& & Cold, moist & 0.03 & 0.02 \\
& & Cool, saturated & 0.03 & 0.02 \\
\hline & & $385-1044$ & 0.05 & 0.01 \\
Annual & & $1044-1881$ & 0.12 & 0.03 \\
precipitation & 0.22 & $1881-3732$ & 0.52 & 0.11 \\
(mm) & & $3732-5456$ & 0.25 & 0.06 \\
& & $5456-6851$ & 0.05 & 0.01 \\
\hline & & $4.12-7.79$ & 0.05 & 0.00 \\
Minimum & & $7.79-10.59$ & 0.09 & 0.01 \\
temperature & 0.07 & $10.59-13.08$ & 0.15 & 0.01 \\
(Celsius) & & $13.08-16.13$ & 0.36 & 0.03 \\
& & $16.13-20.00$ & 0.36 & 0.02 \\
\hline & $163.78-188.74$ & 0.05 & 0.00 \\
Solar radiation & & $188.74-205.95$ & 0.11 & 0.01 \\
(W/m ${ }^{2}$ ) & $0.05 .95-221.44$ & 0.12 & 0.01 \\
& & $221.44-238.22$ & 0.33 & 0.02 \\
& & $238.22-273.52$ & 0.39 & 0.03 \\
\hline
\end{tabular}


All calculated weights are then integrated in ArcGIS version 10.1 (ESRI, Redlands, CA, USA) for the weighted sum operation to obtain the AHP decision surface that shows land suitability for banagrass production on Hawaii and Maui Islands (Figure 4). This figure shows that total land areas for possible use of banagrass production on Hawaii and Maui Islands are 44,754 ha and 10,565 ha, respectively. These areas account for a small portion of the total land areas on both islands: $4.28 \%$ on Hawaii Island and 5.59\% on Maui Island. The level of land suitability for banagrass production based on AHP results is shown with scores ranging from 0 to 100. A higher score indicates a higher suitability level. Figure 4 shows the highest suitable score for banagrass production is measured at 41 and the lowest score at 4 . Areas with a suitability score of 41 are most suitable for banagrass production. These land areas are on both Hawaii and Maui Islands and concentrated along coastal areas (specifically located near Hawi and Kapaau areas toward the north and northeast sections of Hawaii Island and close to the northern coastal areas to the east of Kahului port on Maui Island). This figure also suggests that more suitable land areas tend to be located in low elevation areas near the shore on the wet side on both islands.

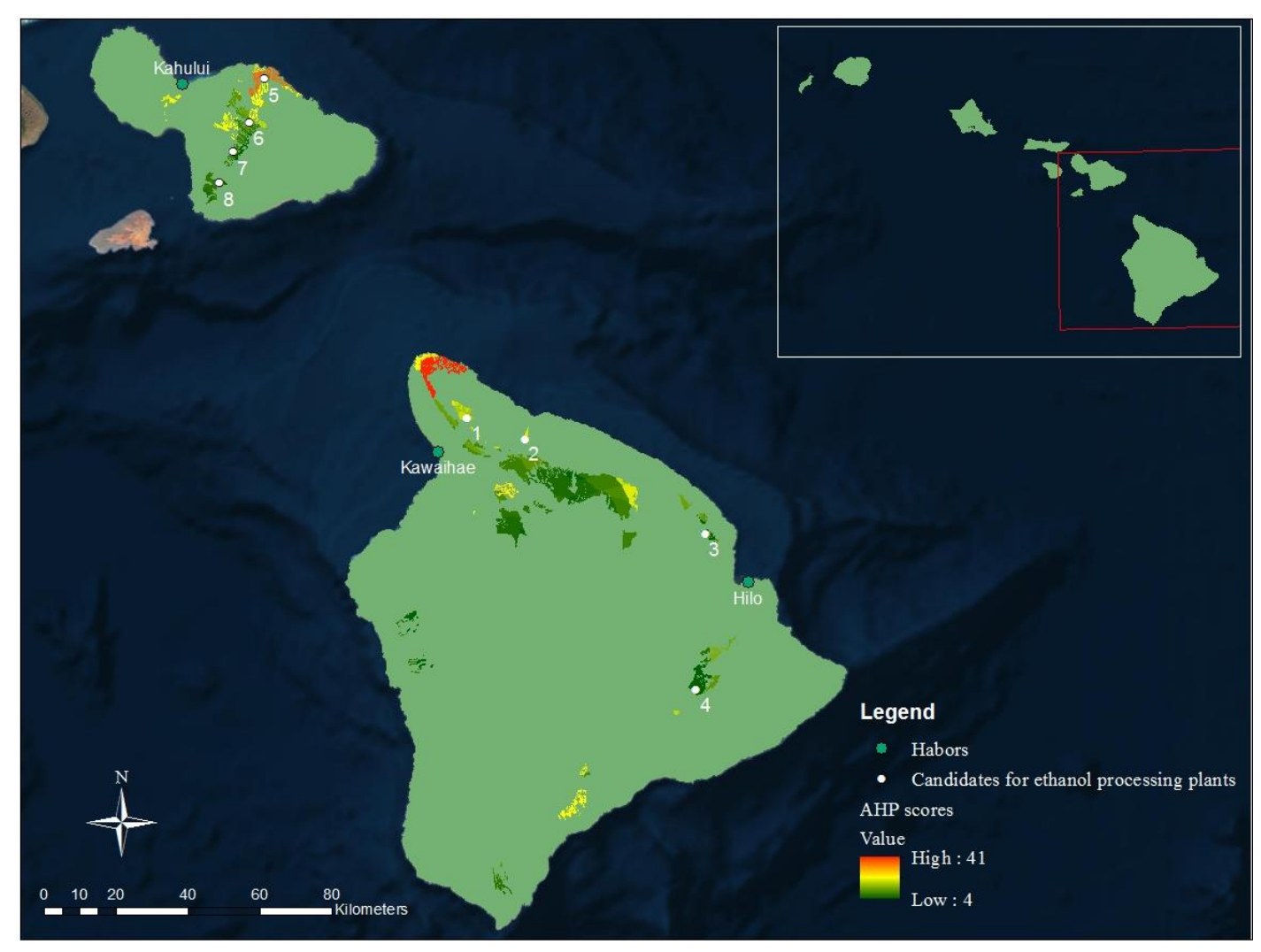

Figure 4. Suitable land areas used for banagrass production.

The estimation of banagrass yield in this study is based on rain-fed conditions. The AHP results indicate that soil temperature and soil moisture regimes play a major role in banagrass production. By comparing the spatial distribution of all criteria, we see the spatial agreement among the criteria. For example, areas with a hot and wet soil condition also have precipitation ranging from 1044 to $3732 \mathrm{~mm}$ per year and have higher minimum temperatures and solar radiation levels. The estimated banagrass yield is primarily based on soil temperature and soil moisture regimes (see [1] pp. 5-14). The data collected from several field trials on Maui Island during the 2012-2015 period are used to validate the estimated yield data [42]. The results are shown in Table 3. 
Table 3. Estimated potential banagrass yield.

\begin{tabular}{|c|c|c|c|c|c|}
\hline Islands & $\begin{array}{c}\text { Soil } \\
\text { Temperature }\end{array}$ & $\begin{array}{c}\text { Soil } \\
\text { Moisture }\end{array}$ & $\begin{array}{l}\text { Area } \\
\text { (ha) }\end{array}$ & $\begin{array}{l}\text { Estimated Average } \\
\text { Yield (Dry Ton/ha) }\end{array}$ & $\begin{array}{l}\text { Total Estimated } \\
\text { Yield (Dry Tons) }\end{array}$ \\
\hline \multirow{5}{*}{ Maui } & Cool & Wet & 1197 & 18.53 & 22,180 \\
\hline & Cool & Moist & 6228 & 18.53 & 115,405 \\
\hline & Hot & Dry & 308 & 0 & 0 \\
\hline & Hot & Moist & 3140 & 21.00 & 65,940 \\
\hline & Total & & 10,873 & & 203,525 \\
\hline \multirow{10}{*}{ Hawaii } & Cool & Moist & 18,211 & 18.53 & 337,450 \\
\hline & Cool & Wet & 880 & 18.53 & 16,306 \\
\hline & Cool & Saturated & 4326 & 14.82 & 64,111 \\
\hline & Hot & Moist & 2181 & 21.00 & 45,801 \\
\hline & Hot & Wet & 3495 & 37.56 & 131,272 \\
\hline & Hot & Dry & 2534 & 0 & 0 \\
\hline & Cold & Moist & 14,513 & 8.15 & 118,281 \\
\hline & Cold & Wet & 1148 & 9.63 & 11,055 \\
\hline & Cold & Saturated & 12,212 & 0 & 0 \\
\hline & Total & & 59,500 & & 724,277 \\
\hline Total & & & 70,373 & & 927,802 \\
\hline
\end{tabular}

The area with the highest banagrass yield is found on Hawaii Island, with a yield of 37.56 dry tons/ha/year. This land is characterized by a hot and wet soil regime. Hot and moist soil produces the second highest yield of 21 dry tons/ha/year on both islands. Land areas with cool soil temperatures produce lower yields as compared to hot soil land. Cold and moist soil conditions yield 8.15 dry tons/ha/year. Lands with either hot and dry or cold and saturated regimes are expected to have zero yield.

The land suitability model also suggests four possible locations for an ethanol processing plant on each island (see Figure 4), with the first four located on Hawaii Island (numbered from 1 to 4 ). The other possible four locations, numbered 5 to 8 , are located on Maui Island. Location 1 is nearest to the highest banagrass-yielding areas on Hawaii Island but is $24.5 \mathrm{~km}$ away from Kawaihae port. The ethanol processing plant location 2 is also closer to Kawaihae port, while the other two location candidates are closer to Hilo port. Of the four possible locations for an ethanol processing plant on Maui Island, location 5 is closest to the highest banagrass-yielding land, while the other three locations are situated to the south. A linear programming (LP) model is used to minimize ethanol production costs at each possible location in order to choose the lowest cost location.

\subsection{LP Model}

The LP model selects the ethanol processing plant location and banagrass feedstock production land areas based on cost minimization. The ethanol target level of $92,548,831$ gallons to meet $20 \%$ of the state's highway fuel demand is calculated based on 2014 gasoline consumption report by the State of Hawaii-Department of Business, Economic Development \& Tourism [24]. The LP model finds this target is not attainable given the availability of land resources for banagrass production on Hawaii and Maui Islands. By using the stipulated land available on both islands, the model estimates that banagrass production/ethanol processing can potentially satisfy only $16.04 \%$ of the state's mandated target (approximately 74,224,160 gallons). The cost of ethanol production varies according to the locations of ethanol processing plant. The cost of ethanol production exceeds $\$ 6 /$ gallon for all processing sites.

Table 4 suggests that smaller ethanol processing plants produce lower-cost ethanol than larger scale plants. The highest cost is found at the largest plant capacity of about 74 MGY and followed by second largest plant capacity of about 45 MGY. The lowest cost is found at the plant capacity of 
about 9 MGY. These costs vary corresponding to different plant locations. Also, the cost of ethanol production at any processing plants on Hawaii Island is lower than on Maui Island. This is because Hawaii has more high-quality land areas than Maui. Although average estimated banagrass yield was found to be higher on Maui than on Hawaii (18.71 dry tons/ha vs. 12.17 dry tons/ha), Hawaii has more concentrated high-quality land that potentially can produce the highest banagrass yields e.g., 37.56 dry tons / ha on 3495 ha while no land on Maui has this potential yield. Land areas that could produce the second and third highest yields of 21.00 and 18.53 dry tons/ha were found on 2181 ha and 19,091 ha for Hawaii and on 3140 ha and 7425 ha for Maui, respectively.

Table 4. Estimated cost of ethanol production for different ethanol production levels.

\begin{tabular}{|c|c|c|c|c|c|c|c|c|}
\hline \multirow{2}{*}{$\begin{array}{l}\text { Ethanol } \\
\text { Plants }\end{array}$} & \multicolumn{8}{|c|}{ Ethanol Production Levels } \\
\hline & \multicolumn{2}{|c|}{$\begin{array}{c}\text { 16.04\% of State's Demand } \\
(74,224,160 \text { Gallons })\end{array}$} & \multicolumn{2}{|c|}{$\begin{array}{c}10 \% \text { of State's Demand } \\
(46,274,415 \text { Gallons })\end{array}$} & \multicolumn{2}{|c|}{$\begin{array}{l}5 \% \text { of State's Demand } \\
(23,137,208 \text { Gallons })\end{array}$} & \multicolumn{2}{|c|}{$\begin{array}{c}2 \% \text { of State's Demand } \\
(9,254,883 \text { Gallons })\end{array}$} \\
\hline Plant 1 & 465,936 & 6.28 & 206,057 & 4.45 & 91,294 & 3.95 & 30,589 & 3.31 \\
\hline Plant 2 & 470,187 & 6.33 & 208,590 & 4.51 & 98,089 & 4.24 & 32,484 & 3.51 \\
\hline Plant 5 & 738,712 & 9.95 & 386,353 & 8.35 & 138,325 & 5.98 & 39,314 & 4.25 \\
\hline Plant 6 & 736,398 & 9.92 & 384,888 & 8.32 & 137,564 & 5.95 & 39,150 & 4.23 \\
\hline Plant 7 & 737,676 & 9.94 & 385,646 & 8.33 & 137,891 & 5.96 & 39,306 & 4.25 \\
\hline Plant 8 & 740,751 & 9.98 & 387,513 & 8.37 & 138,757 & 6.00 & 39,595 & 4.28 \\
\hline
\end{tabular}

Processing plant 1 produces ethanol at the lowest cost as compared to the other plants. This processing plant is located near areas with potentially the highest banagrass yields and close to Kawaihae harbor. As a result (lower feedstock and transportation costs), this location is chosen for building the ethanol processing plant. Table 5 presents detailed LP model results on ethanol production costs for different ethanol production levels: (i) 20\% mandated target level; (ii) 10\% of state's highway fuel demand; (iii) $5 \%$ of state's highway fuel demand; and (iv) $2 \%$ of state's highway fuel demand with ethanol processing plant 1 . The results provide insights into the importance of land locations for feedstock production as a key component in the ethanol production process.

Table 5. Cost analysis of ethanol production for ethanol processing plant 1.

\begin{tabular}{|c|c|c|c|c|}
\hline & $\begin{array}{l}16.04 \% \text { of State's } \\
\text { Demand }\end{array}$ & $\begin{array}{l}10 \% \text { of State's } \\
\text { Demand }\end{array}$ & $\begin{array}{l}5 \% \text { of State's } \\
\text { Demand }\end{array}$ & $\begin{array}{l}2 \% \text { of State's } \\
\text { Demand }\end{array}$ \\
\hline Ethanol production levels (gallons) & $74,224,160$ & $46,274,415$ & $23,137,208$ & $9,254,883$ \\
\hline Total feedstock produced (dry tons) & 927,802 & 578,430 & 289,215 & 115,686 \\
\hline Total land areas (ha) & 55,319 & 28,629 & 11,903 & 3080 \\
\hline Land areas for feedstock production on Hawaii Island (ha) & 44,754 & 28,629 & 11,903 & 3080 \\
\hline Land areas for feedstock production on Maui Island (ha) & 10,565 & 0 & 0 & 0 \\
\hline Average banagrass yield (dry tons/ha) & 16.77 & 20.20 & 24.30 & 37.56 \\
\hline \multicolumn{5}{|l|}{ Cost of feedstock production } \\
\hline Total cost $(\$)$ & $200,732,807$ & $98,068,432$ & $40,774,889$ & $10,551,011$ \\
\hline Unit cost (\$) & 2.70 & 2.12 & 1.76 & 1.14 \\
\hline Percentage of total ethanol cost (\%) & 43.08 & 47.59 & 44.66 & 34.49 \\
\hline \multicolumn{5}{|l|}{ Cost of feedstock transportation } \\
\hline Total cost $(\$)$ & $118,486,156$ & $16,518,649$ & $4,784,315$ & $1,743,832$ \\
\hline Unit cost (\$) & 1.60 & 0.36 & 0.21 & 0.19 \\
\hline Percentage of total ethanol cost (\%) & 25.43 & 8.02 & 5.24 & 5.70 \\
\hline \multicolumn{5}{|l|}{ Cost of Ethanol conversion } \\
\hline Total cost $(\$)$ & $133,268,276$ & $83,084,962$ & $41,542,482$ & $16,616,992$ \\
\hline Unit cost (\$) & 1.80 & 1.80 & 1.80 & 1.80 \\
\hline Percentage of total ethanol cost (\%) & 28.60 & 40.32 & 45.50 & 54.32 \\
\hline \multicolumn{5}{|l|}{ Cost of Ethanol transportation } \\
\hline Total cost $(\$)$ & $13,449,073$ & $8,384,709$ & $4,192,354$ & $1,676,942$ \\
\hline Unit cost (\$) & 0.18 & 0.18 & 0.18 & 0.18 \\
\hline Percentage of total ethanol cost (\%) & 2.89 & 4.07 & 4.59 & 5.48 \\
\hline Total cost $(\$)$ & $465,936,311$ & $206,056,751$ & $91,294,040$ & $30,588,777$ \\
\hline Unit cost (\$/gallon) & 6.28 & 4.45 & 3.95 & 3.31 \\
\hline
\end{tabular}


The LP model results suggest that if all land resources available are used for feedstock production, a total amount of 74,224,160 gallons of ethanol can be produced from 927,802 dry tons of banagrass. Total land areas used for production on Hawaii and Maui Islands are 44,754 ha and 10,565 ha, respectively. Interisland shipping of feedstock is required to transport banagrass from Maui to Hawaii for ethanol processing. This results in a high cost of feedstock transportation, accounting for $25.43 \%$ of total ethanol cost. However, the largest contribution to total cost comes from feedstock production, with a cost share of $43.08 \%$, followed by the cost of ethanol conversion with a $28.60 \%$ share. The smallest cost share is the cost of ethanol transportation, with $2.89 \%$. In sum, all of these cost components contribute to the high cost of ethanol production in Hawaii (estimated at \$6.28/gallon).

Unit or average cost declines with a smaller scale of ethanol production. The per gallon cost decreases to $\$ 4.45$ /gallon, $\$ 3.95 /$ gallon, and $\$ 3.31$ /gallon for ethanol production levels to meet $10 \%$, $5 \%$, and $2 \%$ of state's highway fuel demands, respectively. The cost of ethanol conversion used in this study was based on variable costs and capital costs for a 1MGY facility with corresponding costs of $\$ 1.19$ /gallon and $\$ 600,700$ respectively [46]. As a result, this constant cost does not affect the per gallon cost of ethanol and equals $\$ 1.80$ /gallon for all ethanol production levels [46]. Ethanol transportation includes ground transportation from the processing plant to Kawaihae port and interisland shipping to Oahu. The calculation is for both ground transportation and interisland shipping on a per-gallon basis $[48,50]$. As a result, this per gallon cost is fairly constant at $\$ 0.18 /$ gallon for all ethanol production levels. The key components directly affecting the cost of ethanol production are feedstock production costs and feedstock transportation costs. These costs largely depend on the location of production lands as they affect banagrass yields and hauling distances for feedstock transportation. From Table 5, feedstock production is the principal cost category for ethanol production.

To meet the $10 \%$ or less of state fuel demand, only production on Hawaii Island is required. For smaller scales of ethanol production, the amount of feedstock required for ethanol conversion is less. The LP model selects higher land quality areas first, followed by lower quality land. As shown in Table 5, average banagrass yield increases substantially from 16.77 dry tons/ha for $16.04 \%$ of state demand to 20.20 dry tons/ha, 24.30 dry tons/ha, and 37.56 dry tons/ha for ethanol production levels of $10 \%, 5 \%$, and $2 \%$ of the state highway fuel demand, respectively. As a result, the amount of feedstock required for smaller production scales can be met by using less land, which results in lower production costs.

The location of the production land areas relative to the ethanol processing plant also matters. The land suitability and LP models indicate that processing plant 1 is located near the highest land quality areas that have the highest banagrass yields and the lowest ethanol production costs compared to other processing plant locations. For this banagrass production scenario, production only occurs on Hawaii Island, which results in a decrease in feedstock transportation costs and interisland shipping for transporting feedstock from Maui Island to Hawaii Island (for processing). Per gallon ethanol cost of feedstock transportation is reduced from $\$ 1.60$ /gallon for the $16.04 \%$ of state demand level scenario to $\$ 0.36, \$ 0.21$, and $\$ .19$ for the ethanol production levels of $10 \%, 5 \%$, and $2 \%$, respectively (see Table 5).

Given the availability of land, this study finds that the lowest cost of ethanol production, estimated at $\$ 3.31$ /gallon, can be achieved at a smaller scale that satisfies about $2 \%$ of the state highway fuel demand. Feedstock production occurs only on the highest quality land areas and ethanol processing is at plant location 1 on Hawaii Island (Figure 5). This cost, however, is higher than the average imported ethanol price of $\$ 3 /$ gallon based on [2] and discussion with personnel from the Hawaii Department of Business, Economic Development \& Tourism.

As discussed above, the key factor directly affecting the costs of ethanol production is banagrass yield. A higher yield results in less land area needed for production, which reduces the cost of feedstock production. This study proceeds with a sensitivity analysis to determine the percentage increase in banagrass yield needed to reduce ethanol production costs to the average imported ethanol price (\$3.00/gallon). Detailed sensitivity analysis results are presented in Table 6. 


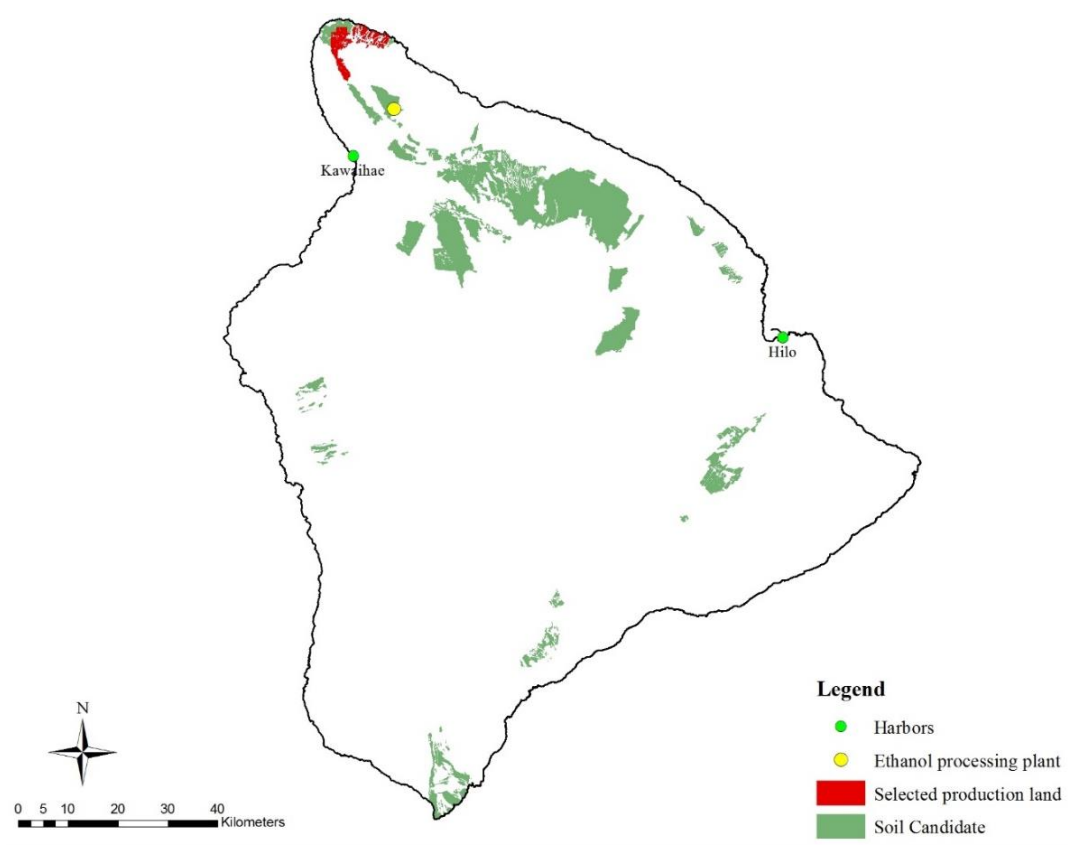

Figure 5. Spatial distribution of selected ethanol processing site and banagrass production land areas to meet the ethanol production level of $2 \%$ of the state's highway fuel demand for 2020.

Table 6. Banagrass yield increase to equal the average imported price in Hawaii to meet $2 \%$ of the state's highway fuel demand.

\begin{tabular}{cc}
\hline & Values \\
\hline Ethanol production level (gallons) & $9,254,883$ \\
Total feedstock produced (dry tons) & 115,686 \\
Average banagrass yield (dry tons $/$ ha) & 50.92 \\
Land areas for feedstock production (ha) & 2272 \\
Cost of feedstock production (\$) & $7,783,224$ \\
Cost of feedstock transportation (\$) & $1,687,491$ \\
Cost of Ethanol conversion $(\$)$ & $16,616,992$ \\
Cost of Ethanol transportation $(\$)$ & $1,676,942$ \\
Total cost (\$) & $27,764,649$ \\
Unit cost (\$/gallon) & 3.00 \\
\hline
\end{tabular}

Sensitivity analysis finds that the cost of ethanol production is equal to the average imported ethanol price if banagrass yield increases by $35.56 \%$ to 50.92 dry tons/ha. This result is primarily due to the decrease in production land areas that leads to the decrease in feedstock production costs. The required production land area is $2272 \mathrm{ha}$. The costs of feedstock production are calculated at $\$ 7,783,224$. This is noticeably lower as compared to the feedstock production cost of $\$ 10,551,011$ for $2 \%$ of the state's demand (Table 5). Given these results, further improvements in feedstock production play a crucial role in making locally produced ethanol competitive with imported sources. The Black and Veatch study [1] estimates low (37.56 dry tons/ha), medium (66.22 dry tons/ha), and high (94.64 dry tons/ha) yields for potential banagrass production on the highest productive lands on Hawaii Island. The estimated ethanol cost of $\$ 3.31 /$ gallon shown in Table 5 was based on the low banagrass yield scenario (37.56 dry tons/ha from [1]). Banagrass yield of 50.92 dry tons/ha is required to meet the average imported ethanol price. This yield level falls in between the low and medium yields estimates made by Black \& Veatch (2010). The diversified crops report 16 reported banagrass yield of 64.24 and 74.13 dry tons/ha/year for plant and ratoon crops, respectively, from the field trial [51]. These field trial yield results suggest that it is possible to produce ethanol at a price equal or lower than the average imported ethanol price if banagrass yield increases at least $35.56 \%$. 


\section{Conclusions}

Study results indicate that Hawaii's renewable fuels target of $20 \%$ of the state's highway fuel demand is not achievable by using all land resources for banagrass production on both Hawaii and Maui Islands. Rather, only 74,224,160 gallons, accounting for $16.04 \%$ of the state's highway fuel demand, can be potentially produced at a cost of $\$ 6.28 /$ gallon. However, this cost is more than double the average imported ethanol price of $\$ 3 /$ gallon for the state of Hawaii.

The selection of feedstock production areas and the location of the ethanol processing plant play a crucial role in minimizing overall ethanol production costs given the available ethanol processing technology. The LP model is an optimizing procedure to minimize ethanol production costs. The generated solution locates the ethanol processing plant near the more productive land areas on both islands.

These findings suggest that for Hawaii, a smaller operational scale is warranted. For instance, a production capacity level of about 9 MGY (which meets about $2 \%$ of state's highway fuel demand) results in an ethanol cost of $\$ 3.31$ /gallon. Ethanol production costs at or below $\$ 3.00 /$ gallon would require higher banagrass yields. Using higher potential banagrass yield scenarios from [1], sensitivity analysis was applied to different rates of yield increases. Results from the sensitivity analysis show that the cost of ethanol production can be reduced to the level of the average price of ethanol imports or lower, but this requires an increase in yield of at least $35.56 \%$. This result suggests that banagrass-based ethanol production can possibly be produced in Hawaii Island to meet about $2 \%$ of the state's highway fuel demand at a cost below the average price of ethanol imports. As a result, alternative renewable resources are needed to meet Hawaii's 20\% renewable fuels target by 2020 .

Acknowledgments: We would like to thank Richard Ogoshi for his expertise and knowledge of banagrass production. This study was supported by ONR Grant N00014-12-1-0496 and USDA-NIFA-9008-003540.

Author Contributions: Chinh Tran designed and carried out the analysis, interpreted the results, and wrote this manuscript. John Yanagida contributed to the design and supervised the AHP process and linear programming.

Conflicts of Interest: The authors declare no conflict of interest.

\section{Abbreviations}

The following abbreviations are used in this manuscript:

LP Linear programming

AHP Analytic Hierarchy Process

MGY Million gallons per year

\section{References}

1. Black \& Veatch. The Potential for Biofuels Production in Hawai'i; B\&V Project Number 147375; Hawaii Department of Business Economic Development and Tourism: Honolulu, HI, USA, 2010.

2. DBEDT. Hawaii Economic Issues: State of Hawaii Energy Data and Trends. Available online: http:// files.hawaii.gov/dbedt/economic/data_reports/reports-studies/energy-data-trend-2014.pdf (accessed on 9 September 2015).

3. ICF International, Poten \& Partners. Hawaii Refinery Task Force 2014; ICF International: Fairfax, VA, USA, 2014.

4. Surles, T.; Foley, M.; Turn, S.; Staackmann, M. A Scenario for Accelerated Use of Renewable Resources for Transportation Fuels in Hawaii; University of Hawaii: Honolulu, HI, USA, 2009.

5. Coffman, M.; Surles, T.; Konan, D. Analysis of the Impact of Petroleum Prices on the State of Hawaii's Economy; University of Hawaii: Honolulu, HI, USA, 2007.

6. Foley, M.; Turn, S.; Staackmann, M.; Surles, R. A Scenario for Accelerated Use of Renewable Resources for Transportation Fuels in Hawaii; University of Hawaii: Honolulu, HI, USA, 2007.

7. Surles, T.; Staackmann, M. Integrated Summary Report: Evaluation of Economic Impacts Due to Changes in Petroleum Prices and Utilization; University of Hawaii, Hawaii Natural Energy Institute: Honolulu, HI, USA, 2007.

8. HI. Rev Stat 196-42; House Bill: Honolulu, HI, USA, 2013. 
9. ICF International, Poten \& Partners. Hawaii Refinery Task Force-Refinery Closure Report; ICF International: Fairfax, VA, USA, 2013.

10. DBEDT. Hawaii Bioenergy Master Plan in Response to Act 253, Session Laws of Hawaii 2007-Report to the Twenty-fifth Legislature, State of Hawaii; Department of Business, Economic Development \& Tourism: Honolulu, HI, USA, 2009.

11. HNEI. Hawaii Bioenergy Master Plan-Volume I; University of Hawaii: Honolulu, HI, USA, 2009.

12. Keffer, V.I.; Evans, D.; Turn, S.; Kinoshita, C. Potential for Ethanol Production in Hawaii; University of Hawaii: Honolulu, HI, USA, 2006.

13. Keffer, V.I.; Turn, S.Q.; Kinoshita, C.M.; Evans, D.E. Ethanol technical potential in Hawaii based on sugarcane, banagrass, Eucalyptus, and Leucaena. Biomass Bioenerg. 2009, 33, 247-254. [CrossRef]

14. Kinoshita, C.M.; Zhou, J. Siting Evaluation for Biomass-Ethanol Production in Hawaii; National Renewable Energy Lab.: Golden, CO, USA, 1999.

15. Tran, N.; Illukpitiya, P.; Yanagida, J.F.; Ogoshi, R. Optimizing biofuel production: An economic analysis for selected biofuel feedstock production in Hawaii. Biomass Bioenerg. 2011, 35, 1756-1764. [CrossRef]

16. Mochizuki, J. Three Essays on Lignocellulosic Ethanol Development in Hawai'i: Cross-Disciplinary Analyses Based on Geospatial, Life-Cycle, and General Equilibrium Modeling; University of Hawaii at Manoa: Honolulu, HI, USA, 2013.

17. OSP. Agricultural Lands of Importance to the State of Hawaii; State of Hawaii, Office of Planning: Honolulu, HI, USA, 2001.

18. OSP. State Land Use District Boundary Acreages by Island; State of Hawaii, Office of Planning: Honolulu, HI, USA, 2014.

19. OSP. Office of Planning Download GIS Data. Available online: http://planning.hawaii.gov/gis/downloadgis-data/ (accessed on 14 April 2015).

20. NRCS. Web Soil Survey. Available online: http://websoilsurvey.sc.egov.usda.gov/App/HomePage.htm (accessed on 2 May 2015).

21. ESRI North America Detailed Streets. Available online: http://www.arcgis.com/home/item.html?id= f38b87cc295541fb88513d1ed7cec9fd (accessed on 18 December 2014).

22. Giambelluca, T.W.; Chen, Q.; Frazier, A.G.; Price, J.P.; Chen, Y.-L.; Chu, P.-S.; Eischeid, J.K.; Delparte, D.M. Online rainfall atlas of Hawai'i. Bull. Am. Meteorol. Soc. 2013, 94, 313-316. [CrossRef]

23. Giambelluca, T.W.; Shuai, X.; Barnes, M.L.; Alliss, R.J.; Longman, R.J.; Miura, T.; Chen, Q.; Frazier, A.G.; Mudd, R.G.; Cuo, L.; Businger, A.D. Evapotranspiration of Hawai'i; University of Hawaii: Honolulu, HI, USA, 2014.

24. DBEDT. Research \& Economic Analysis Monthly Energy Trends. Available online: http://dbedt.hawaii. gov/economic/energy-trends-2/ (accessed on 18 August 2015).

25. EIA U.S. Energy Information Administration (EIA). Available online: http://www.eia.gov/ (accessed on 18 August 2015).

26. CGIAR-CSI Shuttle Radar Topography Mission (SRTM) 90-m Resolution Digital Elevation Model (DEM). Available online: http:/ / srtm.csi.cgiar.org/ (accessed on 2 March 2015).

27. MapCruzin Natural Disaster Series: Download Free Volcano GIS Shapefile. Available online: http:// www.mapcruzin.com/natural-disaster-shapefiles/volcano-arcgis-shapefile-download.htm (accessed on 20 January 2015).

28. CFDC; Nebraska Ethanol Board. A Guide for Evaluating the Requirements of Ethanol Plants; The Clean Fuels Development Coalition and The Nebraska Ethanol Board in cooperation with The U.S. Department of Agriculture: Bethesda, MD, USA, 2006.

29. Van den Berg, J.; Rebe, M.; De Bruyn, J.; Van Hamburg, H. Developing habitat management systems for gramineous stemborers in South Africa. Int. J. Trop. Insect Sci. 2001, 21, 381-388. [CrossRef]

30. Wu, J.; Wang, J.; Strager, M.P. A two-stage GIS-based suitability model for siting biomass-to-biofuel plants and its application in West Virginia, USA. Int. J. For. Eng. 2011, 22, 28-38.

31. FAO. Pennisetum Purpureum. Available online: http://www.fao.org/ag/AGP/AGPC/doc/Gbase/DATA/ Pf000301.HTM (accessed on 22 April 2015).

32. Zambelli, P.; Lora, C.; Spinelli, R.; Tattoni, C.; Vitti, A.; Zatelli, P.; Ciolli, M. A GIS decision support system for regional forest management to assess biomass availability for renewable energy production. Environ. Model. Softw. 2012, 38, 203-213. [CrossRef] 
33. Şener, S..; Şener, E.; Nas, B.; Karagüzel, R. Combining AHP with GIS for landfill site selection: A case study in the Lake Beyşehir catchment area (Konya, Turkey). Waste Manag. 2010, 30, 2037-2046. [CrossRef] [PubMed]

34. Mohit, M.A.; Ali, M.M. Integrating GIS and AHP for land suitability analysis for urban development in a secondary city of Bangladesh. J. Alam Bina 2006, 8, 1-20.

35. Bunruamkaew, K.; Murayam, Y. Site suitability evaluation for ecotourism using GIS \& AHP: A case study of Surat Thani province, Thailand. Procedia-Soc. Behav. Sci. 2011, 21, 269-278.

36. Ferraris, R. The effect of photoperiod and temperature on the first crop and ratoon growth of Pennisetum purpureum Schum. Crop Pasture Sci. 1978, 29, 941-950. [CrossRef]

37. Ferraris, R.; Mahony, M.J.; Wood, J.T. Effect of temperature and solar radiation on the development of dry matter and attributes of elephant grass (Pennisetum purpureum Schum.). Crop Pasture Sci. 1986, 37, 621-632. [CrossRef]

38. Ferraris, R.; Sinclair, D.F. Factors affecting the growth of Pennisetum purpureum in the wet tropics. II. Uninterrupted growth. Crop Pasture Sci. 1980, 31, 915-925. [CrossRef]

39. Jenks, G.F. The data model concept in statistical mapping. Int. Yearb. Cartogr. 1967, 7, 186-190.

40. De FSM Russo, R.; Camanho, R. Criteria in AHP: A systematic review of literature. Procedia Comput. Sci. 2015, 55, 1123-1132. [CrossRef]

41. Tsyganok, V.V.; Kadenko, S.V.; Andriichuk, O.V. Significance of expert competence consideration in group decision making using AHP. Int. J. Prod. Res. 2012, 50, 4785-4792. [CrossRef]

42. Ogoshi, R. Banagrass Yields from Field Trials; Email communication: Honolulu, HI, USA, 2015.

43. Freedman, C. Maui County Water Use and Development Plan; Haiku Design \& Analysis: Maui, HI, USA, 2009.

44. Fukunaga \& Associates, Inc. Hawaii County Water Use and Development Plan Update-Hawaii Water Plan; Fukunaga \& Associates, Inc.: Honolulu, HI, USA, 2010.

45. ESRI ArcGIS online: North America Detailed Streets. Available online: http://www.arcgis.com/home/item. html?id=f38b87cc295541fb88513d1ed7cec9fd (accessed on 18 December 2014).

46. Kumar, D.; Murthy, G.S. Impact of pretreatment and downstream processing technologies on economics and energy in cellulosic ethanol production. Biotechnol. Biofuels 2011. [CrossRef] [PubMed]

47. Mahmudi, H.; Flynn, P.C. Rail vs. truck transport of biomass. Appl. Biochem. Biotechnol. 2006, 129, 88-103. [CrossRef]

48. Kocoloski, M.; Griffin, W.M.; Matthews, H.S. Impacts of facility size and location decisions on ethanol production cost. Energy Policy 2011, 39, 47-56. [CrossRef]

49. Young Brothers Ltd. Feedstock Inter-Island Shipping Costs; Email communication: Honolulu, HI, USA, 2015.

50. HNEI. Biofuel Feedstock Inter-Island Transportation; University of Hawaii: Honolulu, HI, USA, 2012.

51. Osgood, R.V.; Dudley, N.S.; Jakeway, L.A. A Demonstration of Grass Biomass Production on Molokai; Hawaii Agriculture Research Center: Honolulu, HI, USA, 1996. 